\title{
Management of the enterprise economic security system in network economy conditions: essence, basic components and the diagnosing mechanism
}

\author{
Hanna Matukova ${ }^{1, *}$,Eduard Mokriak ${ }^{1}$, and Daria Matukova-Yaryha² \\ ${ }^{1}$ Kryvyi Rih Economic Institute of Kyiv National Economic University named after Vadym Hetman, Kryvyi Rih, Ukraine \\ ${ }^{2}$ National Medical University named after O.O. Bohomolets, Kyiv, Ukraine
}

\begin{abstract}
The article determines the role and the meaning of network structures in modern economy. There are revealed risks and threats in the activity of economic entities that are part of network structures. The notion of economic security in the network economy is revealed. The structure of the economic security system of network companies is formed, its basic components being characterized. Basic components of the economic security system in the network economy under current conditions are analysed, some problems of ensuring economic security and ways of their solution are determined. A complex mechanism of diagnosing the enterprise economic security is elaborated. The article considers main ways of ensuring economic entities' security by introducing the integrated economic security system to predict and prevent threats to economic security.
\end{abstract}

\section{Problem statement}

At present, the activity of all economic entities without exception is subject to uncertainty and unpredictability. Unstable political, social, economic and demographic situations and numerous external factors of impact strengthen managerial decision-making risks in all aspects of business activities. Enhanced market competitiveness and integration into the world economic space, new managerial and legal forms of business and formation of the global network economy highlight the issues of creating an efficient system of economic security of businesses. To provide high efficiency of the economic activity, economic security control should become a component of the strategic management system of each enterprise.

In market economic conditions, the enterprise economic security depends on that of the state and the region as it is based on available financial, raw material and industrial potentials as well as their prospective development. The enterprise economic security is greatly affected by the degree of thoroughness of the law base, taxing, access to the world sales markets, a region's investment attractiveness and that of a state as a whole.

\section{Review of recent researches and research objective}

Researches in the modern economic theory prove that the economic science has accumulated sufficient theoretical basis in the field of the enterprise economic security. Economic security issues were studied by L. Smoliar, O. Kotenko [1], O. Nosova, O. Makovoz [2], etc. They mostly dealt with the essence of economic security, its various levels, components and indicators to assess its state. Ukrainian scientists T. Vasyltsiv [3], A. Kozachenko [4], O. Arefieva [5], T. Kuzenko [5], O. Palyvoda [6], etc. investigated into economic security. The mentioned scholars' papers contain theoretical substantiation and methods of assessing the condition of the state and enterprise economic security considering national peculiarities of the economic development.

Intensified globalization and internationalization of economic activities in the early decade of the $21^{\text {st }}$ century, the information society boom, creation of economic clusters and networks resulted in new risks and threats for enterprises' activities and determined the need for conducting investigations into economic security in network economy conditions.

P. Drucker [7], O. Sushchenko [8], L. Buzdakov [8], Ya. Hlushchenko [9], Yu. Ivchenko [10], T. Dziaduk [11], V. Martynenko [12], S. Mayadunne, and S. Park [13] and other scholars considered the essence of the network economy, theoretical aspects of network managerial interaction, determined specific risks and threats arising in the activity of network associations and highlighted the necessity of their minimizing.

At the same time, the national scholars did not pay enough attention to the issues of controlling economic security in network economy conditions on both the state level and that of economic entities incorporated into a single economic network.

The article is aimed at analyzing basic components of the enterprise economic security system in network economy conditions in terms of modern realia and developing a diagnosing mechanism of economic security as part of the economic security control process.

\footnotetext{
* Corresponding author: deborah88@ukr.net
} 


\section{Presentation of main research material}

Today, an enterprise should avoid a number of threats in order to adapt to dynamic changes in economy, politics and society. Under market conditions, an enterprise as an open system has to function in the unstable dynamic external environment with its new emphases that call for innovative approaches and development and involve severe competitiveness. The appropriate level of the enterprise economic security provides the basis for the country's social and economic development, especially in the context of Ukraine's accelerated integration into international economic organizations and the global economy.

National and foreign authors have different approaches to defining economic security. The authors of the monograph "Enterprise economic security: essence and provision mechanisms" define economic security as the state of corporate resources (capital, personnel resources, etc.) and business potentials which guarantee their most efficient application to stable functioning and dynamic scientific, technological and social development; the state of protection from negative impacts of external and internal threats, destabilizing factors, etc. [4].

I. Blank treats economic security as a qualitatively and quantitatively determined level of an enterprise's financial state ensuring stable protection of its prioritized balanced financial interests from identified real and potential threats, both internal and external, which create necessary preconditions for financial support of its stable growth both in the current and longer-term periods [2].

O. Arefieva and T. Kuzenko interpret the notion of economic security as the state of efficient use of an enterprise's resources and current market potentials enabling it to prevent external and internal threats, provide long-term survival and sustainable development on the market according to the mission chosen [3].

In present-day conditions, business activity cannot evolve within separate, even "the most independent" enterprises. As it is accentuated in the work by the world famous author in the management theory Peter Drucker, "Management Challenges for the $21^{\text {st }}$ century", a company is a reality for shareholders, creditors, clerks and tax services, yet from the economic point of view, a company is just a fiction. He also states that economic reality is a single economic process that unites suppliers of certain resources, production, sales of end products, past-warranty service and final consumption of certain products and services [7]. Therefore, fighting intercompany obstacles, modern business strives for economic integration within certain integral reproduced economic complexes that comprise an economic network.

Practical needs for passing to network interaction of business structures as a specific form of activity organization are conditioned by the fact that their industrial and economic activity becomes more and more complicated and calls for new methods of management and adaptation to changes in the external environment.

There are different interpretations of a network structure in scientific literature. In our opinion, the most felicitous is the one provided by O. Sushchenko and L. Buzdakova who treat a network structure as a form of arranging economic activity based on network interaction of its participants according to their interests, resources, competences and potential possibilities aimed at obtaining additional profits and increasing their competitive capacity due to flexibility, adaptability and application of the mutual potential of a network [8].

According to L. Smoliar, the major feature determining whether an organizational form belongs to a network is autonomy of economic agents entering repeated acts of exchange, yet there is interdependency in terms of gaining their own profits [1].

The network economy is a set of network organizational formations with their interrelation, interaction and economic relations.

At present, it has been proven that the role of the network economy and electronic commerce systems with Internet-resources is essential in the enterprise economic security. In the report by the European Commission, the global network economy is defined as the environment in which any company or an individual located in any point of the economic system can easily contact any other company or individual at minimum costs regarding joint work, trade, idea exchange, know-how and just for fun [15].

The appearance of the network economy is conditioned by growing scales of enterprises' activities, their entering the interregional and then the international global level. Inter-firm cooperation applied by national and foreign economic entities and their further development results in various managerial formations (clusters, strategic alliances, networks of informal relations, etc.) composed of legally independent enterprises closely interconnected by horizontal connections.

In network economy conditions, management of processes, not of separate functions, prevails actualizing the tasks of forming a collective competitive advantage over all market subjects and structuring markets on the basis of voluntary and stable cooperation of economic entities. The cooperation has a form of joint entrepreneurship, various contract and subcontract relations, franchising schemes, and other integrated associations in which actions are planned and managed jointly.

Unlike the activity of isolated economic entities, formation of network structures results in the synergetic effect. This effect is conditioned by availability of companies' joint interests in the areas based on application of the same or similar technologies, equipment, logistic channels, relations with the same suppliers and consumers, a single infrastructure, dealers, repair maintenance, design and research [6].

When generalizing national scholars' research results in the field of the network economy $[1 ; 2 ; 8 ; 11]$, one can specify the following advantages of network management of economic entities' activity:

- freedom from red tape and formalization;

- high status of informational and staff integration means; - reduction of transaction expenses and ambiguity of the economic activity resulted from enhanced trust of economic entities composing a network; 
- appearance of new business opportunities, access to new technologies, expansion of sales markets;

- provision of companies' flexible activity, their receptivity to innovations, orientation on final consumers as a result of voluntary and long-term cooperation of network participants;

- free mutual access to resources owned by network participants.

At the same time, the network economy is characterized by a number of risks and hazards, the major ones being the following $[2 ; 9 ; 11]$ :

1. IT-risks include lost Internet connection resulted from possible computer equipment failures, deformation of data when transmitting them, virus attacks that can cause data destruction, etc.

2. Risks of losing data confidentiality and safety.

3. Regulatory and legal risks of intellectual property protection.

4. Staff risks involve losses of highly qualified personnel because of high fluctuation of labour force, deficiency of multi-skilled employees, lack of motivation when social support is not encouraged in the network formation concept.

5. Hazards of participants' interest conflict.

6. Hazards of the too complicated character of a network organization are conditioned by heterogeneity of its participants, membership ambiguity, openness of networks, self-management dynamics and uncertainty of planning for network members.

7. Hazards of strengthening dependency of enterprises of a single network are explained by double dependency of network structures - on the market and resources.

8. Hazards of monopolization resulted from possible merge and absorption of enterprises-network members in horizontal integration.

All this calls for reinterpretation of views on economic security and its treatment not only on the level of separate isolated economic entities, but also on the level of their interaction within a certain network and interconnection of network enterprises within national and world economic systems.

The first steps in solving these problems were made by national scientists. V. Vasyltsiv and S. Hrynkevych explored formation of the economic security of Ukraine's business environment. In their opinion, the business economic security "... is a state of safety of economic entities of this field in the process of interacting with the state, other economic entities including those of the informal sector, elements of the institutional environment as well as when creating the public weal and services" [3]. $\mathrm{V}$. Martynenko considered and analyzed threats to the Ukrainian economic security under globalizing economic conditions and presented characteristics and manifestations of these threats [12].

Generalizing various approaches to interpreting the notion of economic security and taking account of modern realia of network structures development, the notion "Economic security in network economy conditions" can be treated as the ability of economic entities composing various network structures to satisfy consumers' needs on local, national and interstate levels on the basis of efficient interaction and joint use of resources and market advantages, countering external and internal threats.

The system ensuring economic security in network economy conditions is associated with a set of economic, legal and law enforcing tasks, protection of enterprise economic interests and property. Creation of the efficient system of managing economic security is a top priority.

The activity of ensuring the enterprise security is aimed at objects of the system of managing the enterprise economic security including various types of activity (industrial, business, supplying, managing, etc.); property and resources (financial, material-technical, informational, intellectual, etc.); personnel, executives, structural departments, services, partners, employees aware of commercial secrets; interaction of independent business units.

\section{Research results}

Efficient management of the economic security system of network organizations is primarily dependent on the right choice of basic components of the economic security system. The enterprise security system cannot be commonplace for all enterprises; it is unique for each economic entity as it depends on the development level and the industrial potential structure, quality of its application and efficiency of industrial activity, personnel qualification, competitive surroundings, etc. The enterprise security system is relatively independent and isolated from similar systems of other enterprises. Yet, the isolation is relative as the enterprise security system is an element of higher-level security, i.e. that of a city, a region, a country.

The issues of ensuring employees' and executives' security, protection of enterprise property, financial and informational resources, industrial and legal security claim special attention of enterprises and organizations making up various network formations. On this assumption, the structure of the enterprise economic security in network economy conditions can be presented as follows (Fig. 1).

Let us consider specific features of managing certain most important components of the enterprise economic security system in network economy conditions.

The industrial component of economic security implies reflection of the conformity level of internal potentials of the enterprises making up network formations with the external ones in the market environment.

A company's fate depends not only and not so much as on the company itself, but also on efficient interaction of all the entities composing "the entire economic chain", which, in Peter Drucker's opinion, includes production, transportation and sales of products, their consumption accompanied by after-sales service and disposal of both industrial and consumption wastes. Only cost-based units operate inside a company. The only profitable unit is the consumer who provides a certain assessment of a company's activity [7]. This makes enterprise management implement active policies aimed at integrating efforts of all the economic chain participants. 
Yet, there are hindering interest conflicts of enterprise owners, participants of this chain.

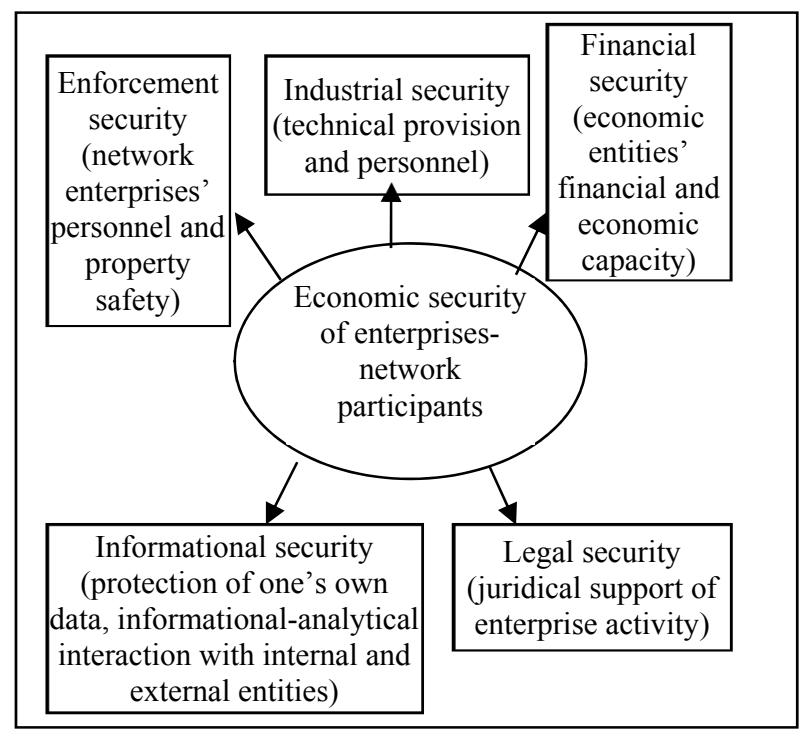

Fig. 1. The structure of the enterprise economic security in network economy conditions (compiled by the authors).

For instance, a food producing enterprise sells its products to a wholesaler who sells the products to another participant of the economic chain - a retailer, selling them to the final consumer - people. However, each participant of the economic chain tries to sell the products to the subsequent agent in the chain for a higher price than the previous one in order to gain a profit. It leads to the fact that the products become too expensive for final consumers. Thus, the interests of the network formation aimed at satisfying the final consumer's needs contradict those of each network participant striving for maximum profits. It can cause each participant's losses.

Transition to economic relations based on logistics can solve the conflicts of interests of the whole economic chain. The logistic concept of economic entities is based on application of the 7R-rule or the logistic mix (similar to the marketing $4 \mathrm{R}$ mix) - ensuring the availability of the right product, in the right quantity and the right condition, of the right place, of the right time, for the right customer, at the right cost. This concept implies interaction of all subjects of the integral economic chain based on the vertical marketing system. Unlike traditional distribution channels composed of a certain number of independent economic entities, each of them trying to gain the highest profits even sacrificing the integral system's maximum profits, vertical marketing systems comprise the entities acting as a single system. In this case, one of the participants of the logistic channel is either a retail owner or provides trade advantages for them and is able to ensure their full cooperation. Vertical marketing systems can be dominated by a producer, a retailer or a wholesaler. These systems appeared as a means of controlling the channel behaviour and preventing conflicts between its separate members with their own aims. Thus, vertical marketing systems are economical in terms of their sizes, have strong positions on the market and avoid effort doubling.
Resource provision is another problem of ensuring the industrial component of economic security in network economy conditions.

The industrial paradigm of the social and economic development has resulted in great achievements in production and consumption volumes in the recent decades. In the $19^{\text {th }}$ century the world GDP increased 3.5fold, while in the $20^{\text {th }}$ century -19 -fold. However, it was achieved by increasing the amount of natural resource mining and processing causing corresponding environment contamination and elimination that threaten further more or less long-term existence of mankind if these trends remain. In the $21^{\text {st }}$ century, escalation of natural resource use is forecast.

With a view to this, the problems of resource provision in the $21^{\text {st }}$ century are going to be urgent and controversial. In the $19^{\text {th }}$ and $20^{\text {th }}$ centuries, prices for natural resources were determined by mining expenses mostly, while in the $21^{\text {st }}$ century they tend to be determined by the amount of potential resources. Besides, there are escalated expenses for prevention of vital environmental losses associated with mining, transportation, production and household consumption of resources (reclamation of disturbed lands, environment protection from harmful gases, waste disposal, etc.). So, problems of changing the industrial structure, life problems to some degree, search for and application of resource-saving technologies will be top priorities of organizational management and call for crucial changes in assessment criteria of efficiency of its activity and behaviour stereotypes set in resource prosperity times.

Resource security is closely connected with the technological one aimed at conformity of technologies applied at enterprises to the best world standards.

Increased production scales in resource deficiency conditions and resulted induced application of potentially dangerous technological processes increase the risk of destructive technological disasters like Chernobyl technogenic catastrophe. Resource (primarily energy) restrictions do not allow refusing current and experimenting with new technological processes which can be even more hazardous like construction of the first experimental energy thermonuclear plants. Probable wide application of biotechnologies, gene engineering in particular, aimed at solving resource problems in the $21^{\text {st }}$ century causes certain threats, which are difficult to forecast and assess today. Here, it is difficult to consider a complex character of forecasting and assessing consequences of practical technological application of new scientific discoveries and inventions. As P. Drucker accentuates "... there is probably a law of nature according to which everything that is actually new (a product, a service, a technology) finds its final sales market and its final application not where their inventors and producers planned to. And no research into either markets or consumers can provide opportunities to predict all that beforehand" [7]. This places a specific responsibility on all the economic subjects, first of all on organizational management, for social and environmental consequences of applying various technological innovations. 
Personnel security is determined by a set of actions and interrelations of employees resulting in efficient enterprise functioning, its ability to resist internal and external impacts and threats associated with personnel. In network economy conditions, steps of controlling the personnel security should target increased educational and qualification levels of employees and network participants through arranging an efficient management system both at separate enterprises and in the network as a whole, ensuring employees' motivation and salaries, increasing their innovative activity and using labour potential efficiently.

Financial security is the state of an enterprise maintaining its financial balance, stability, solvency and liquidity in the long run that satisfies its needs for financial resources and ensures its financial independence for a long period.

Under overwhelming globalization and economy dynamization, escalation of the scale and globalization of financial transactions tending to be disassociated from real production functioning and development are some of the problems of ensuring financial security of economic entities.

Many analysts consider that the financial area is getting more and more disassociated from the industrial one and is functioning as an independent system not only serving production, but also trying to control production and all other areas of human activity to meet the needs for infinite self-growth of financial value (financial capital) [13]. Its development is similar to that of a huge stock exchange with its manipulations by means of various information pyramids which are not associated with evolution of the real economy. There is transformation of a real product movement towards pure informationfinancial schemes, towards the virtual system of a network movement of financial capital resulting in an autonomous virtual capitalism system, which crashes down the real economy. That is why, it is required to 'recover our wits' and balance the industrial, financial and social-cultural spheres, subordinate the integral vector of their interrelated dynamics to human development and self-realization interests [14].

The enterprise legal security is a component of economic security. Law violations in the economic sphere are noted for high public hazards as they threaten basic economic relations, the level of which determines all social areas. Economic offences are the most powerful driver of almost all infringements of the law. There is no exaggeration saying that they provide the basis for all infringements.

Legal security of the enterprise economic activity should be generally treated as the state of protection of economic entities' interests involving systematic obtainment of profits under conditions of decreased business risks from external and internal threats, which have negative economic, managerial, legal and other consequences. In the wider sense, economic and business security can be assessed differently $[10 ; 12]$. Let us specify some basic ways of ensuring enterprises' legal security. From the economic point of view, there is a stable trend of increasing basic financial and economic indices (equity, annual turnover, financial returns, profitability). The above indices reflect the results of the current economic security and its components (legal, informational, industrial, etc.). They may also include such indices as absence of fines and sanctions of the state authorities for breaking the law (for example, tax and antimonopoly laws), absence of losses because of operations with unfair counteragents.

The information component is characterized by expansion of information and telecommunication technologies resulting in negative consequences of their application. From this viewpoint, security can be interpreted as keeping internal and external confidential data protected from leakage or exposure in a variety of forms. From the legal viewpoint, this indicates constant provision of conformity of a company's activity to the law in force and is expressed in absence of claims of law enforcing bodies or counteragents to the company. Besides, there are no losses from operations with external partners due to infringements (intentional or unintentional) provided by the juridical commission of experts of all performed operations as well as the operations and agreements being concluded. Thus, in the most general form, security of a businessman (a firm, an enterprise) being a subject of law is indicated by keeping it as an integral structural formation and a legal entity as well as stable (or growing) values of primary financial and economic indices.

Enforcement security provides protection of interests of each enterprise making up a network formation from physical and moral negative impacts as well as preservation of an enterprise's property. Steps aimed at controlling enforcement security include:

- providing physical and moral security of employees; - protecting an enterprise's property from negative impacts that can cause property loss or reduction of its value;

- providing enforcement aspects of information security (prevention of confidential data thefts by employees who come on business from other enterprises composing the network).

Management of economic security is impossible without diagnosing it. It is important in terms of determining basic parameters of economic entities' further efficient innovative development in network economy conditions as available profits and even highlevel profitability are often accompanied by low competitiveness and technical-engineering potential, high dependency on factors of the external environment, deficiency or even absence of innovations in industrial and management activities. Fig. 2 reveals interrelation of components of the diagnosing mechanism of the enterprise economic security.

To diagnose the enterprise economic security, it is required to take account of the following principles: efficiency; creation of the database of the system controlling the enterprise financial security as the basis for developing steps of preventing real and potential threats; adequacy as a system of indicators to reflect basic quantitative and qualitative trends of changing parameters of the internal and external environments; actuality as periodicity of updating initial data according to the diagnosing aim as data of some period bear the 
informational value only when they characterize changes in a studied object's activity and serve as a signal for managerial decision-making; hierarchy as consideration of connections of an enterprise as a market relations subject; integrity as means of coordinating actions of the system controlling the enterprise economic security to increase efficiency of controlling implemented decisions.

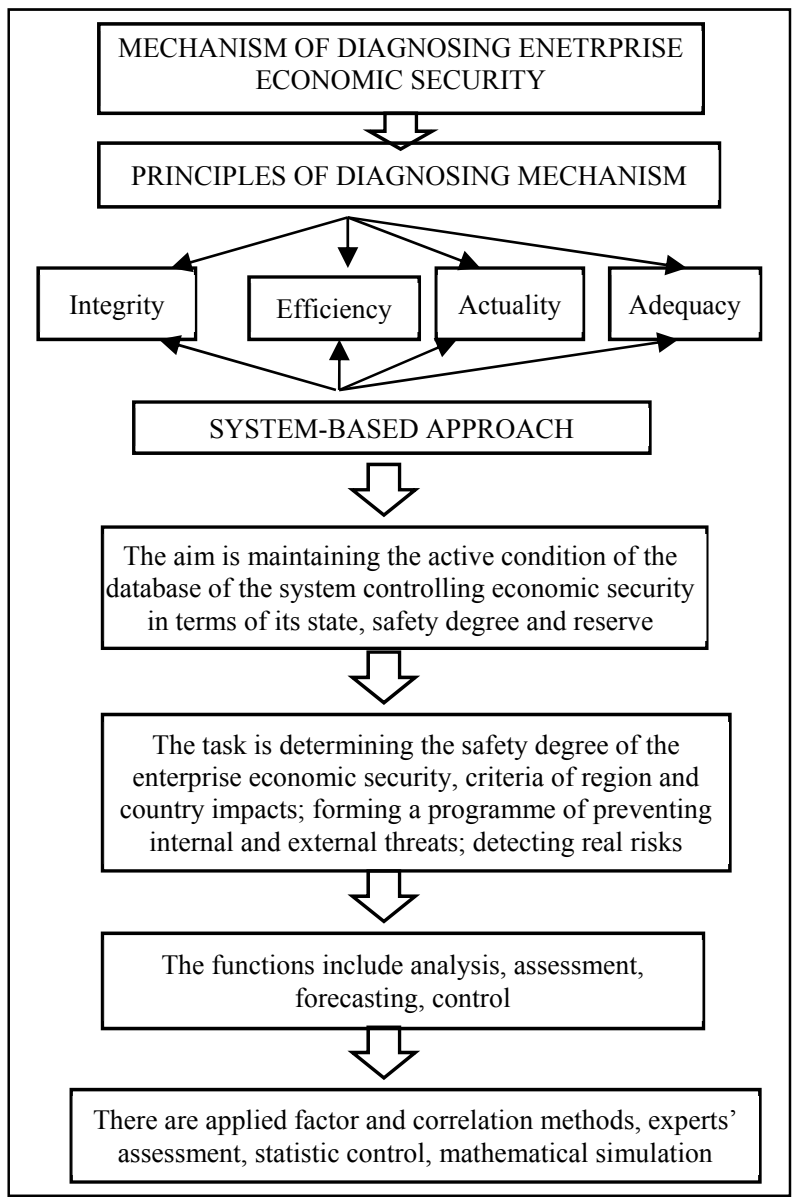

Fig. 2. Components of the mechanism of diagnosing the enterprise economic security (compiled by the authors).

Diagnostics of the enterprise economic security in network economy conditions should be system-based. This approach involves analysis of potential and real threats for each component of economic security in their interconnection and interdependence.

The system of diagnosing the enterprise economic security in network economy conditions is aimed at maintaining the database of the system of managing economic security in terms of its state, potential and reserve.

According to the main aim of the system of diagnosing economic security, there are formulated tasks including determination of the safety degree of the enterprise economic security, criteria of region and country impacts, formation of the programme of preventing external and internal threats, detection of real risks.

A set of interrelated tasks targeting the general aim fulfillment creates functions of diagnosing economic security, which include analysis, assessment, forecasting and control.
Economic security can be diagnosed by various methods. In network economy conditions when diagnosing the economic security of economic entities, it is necessary to apply quantitative and qualitative assessment methods to obtain reliable results.

Management of the enterprise economic security system in network economy conditions should encapsulate the following stages: studying specific features of enterprises making up the network, the market, competitors and personnel; analyzing external and internal threats, determining their reasons and ways of regulation, audit of available means, conformity with possible threats; creation of a new system of the enterprise economic security on the basis of the control system (developing a plan of eliminating detected drawbacks, preparing suggestions of controlling the network); planning monthly expenses for the economic security system functioning; approving the model of the new economic security system, assessing efficiency of the formed system and its improvement. The methods of forming the enterprise economic security system envisage constant control, correction and improvement of ways of the security system formation $[15 ; 16]$.

Top priorities of the enterprise economic security system in network business management include determining interaction of subjects in a model, assessing their significance in an enterprise's profits, measuring interaction parameters in detail, detecting promising lines of network development, forming the system of protection from possible threats to the enterprise economic security and all resource types.

There are distinguished the following directions of ensuring the enterprise economic security in network economy conditions:

- ensuring enterprises' high financial performance and independence;

- providing technological independence, achieving high competitive ability and technical potential;

- achieving high efficiency of the management system;

- achieving personnel's high qualification and intellectual potential;

- reducing impacts of the industrial and economic activity on the environment;

- achieving high quality of legal protection of all aspects of an enterprise's activity;

- ensuring protection of business secrets, informational support of functioning of all enterprise departments, its capital, property, business interests.

\section{Conclusions}

Thus, the research conducted allows concluding that the problems of the enterprise economic security in network economy conditions are new to the national science and require further investigation. Taking account of a variety of approaches to defining economic security and peculiarities of network structures development at present, the following definition of the economic security in network economy conditions is suggested. It is the ability of economic entities composing various network structures to satisfy consumers' needs on local, national 
and interstate levels on the basis of efficient interaction and joint use of resources and market advantages, countering external and internal threats. Analysis of the most essential components of the economic security system of network structures enables distinguishing the problems of ensuring their economic security including conflicts of network association participants' interests, efficient use of resources and resource saving, possible negative consequences of applied information technologies, globalization of financial transactions tending to be more disassociated from functioning and development of real production. The developed mechanism of diagnosing economic security of economic entities in network economy conditions, which is part of management of the economic security system, will enable more efficient detection of risks and threats in network enterprises' activity.

The present-day situation requires from enterprises to have an efficient security mechanism able to act effectively in unusual conditions. Provision of the necessary profit level is one of the essential factors to achieve this goal, it greatly depending on scientific approaches to forming a flexible, efficient production programme, provision of efficient control of information technology systems, intensification of applied information-advertising Internet resources to meet network economy requirements.

\section{References}

1. Smoliar, L.H., Kotenko, O.A.: Merezhevi struktury iak suchasna forma orhanyzatsii ekonomichnoi diialnosti (Network structures as a modern form of organization of economic activity). Efektyvna ekonomika. 12. http://www.economy.nayka.com.ua/ ?op=1\&z=1660 (2012). Accessed 21 Mar 2019

2. Nosova, O.V., Makovoz, O.S.: Ekonomichna bezpeka pidpryiemsva $\mathrm{v}$ umovakh merezhevoi ekonomiky (Economic security of enterprises in network economy conditions). Ekonomichna stratehiia i perspektyvy rozvytku sfery torhivli ta posluh. 1(1), 224-229 (2012)

3. Vasyltsiv, T.H., Hrynkevych, S.S.: Formuvannia seredovyshcha ekonomichnoi bezpeky pidpryiemnytstva $\mathrm{v}$ Ukraini (Formation of the environment of economic security of entrepreneurship in Ukraine). Ekonomichnyi chasopys XXI. 3-4 (1), 24-27 (2015).

4. Kozachenko, H.V., Ponomariov, V.P., Liashenko, O.M.: Ekonomichna bezpeka pidpryiemstva: sutnist ta mekhanizm zabezpechennia (Economic security: essence and provision mechanism). Libra, Kyiv (2003)

5. Arefieva, O.V., Kuzenko, T.B.: Planuvannia ekonomichnoi bezpeky pidpryiemsv (Planning of enterprise economic security). Vyd-vo Yevrop. untu, Kyiv (2005)

6. Palyvoda, O.M.: Otsiniuvannia synerhetychnoho efektu formuvannia klasternykh orhanizatsiinykh struktur (Assessment of the synergetic effect of forming cluster organizational structures). Ekonomichnyi chasopys XXI. 158 (3-4(2)), 48-51 (2016).

7. Drucker, P.: Zadachi menedzhmenta $\mathrm{v}$ XXI veke (Management Challenges for the $21^{\text {st }}$ century). Vilyams, Moscow (2004)

8. Sushchenko, O.A., Buzdakov, L.M.: Rozvytok upravlinnia merezhevymy formamy vzaiemodii biznes-struktur (Development of management of network forms of interaction of business structures) Upravlinnia proektamy ta rozvytok vyrobnytstva. 3, 52-56.

http://www.pmdp.org.ua/images/Journal/39/11 soavb s.pdf (2011). Accessed 21 Mar 2019

9. Hlushchenko, Ya.: Ryzyky pidpryiemstva v merezhevii ekonomitsi (Risks of enterprises in network economy). In: Merezheve suspilstvo: rynok pratsi, suspilni vidnosyny, rol profspilok, pp. 14-15. APSVT, Kyiv. https://www.socosvita.kiev.ua/sites/default/files/Tez y_RT_22_03_\%202018.pdf (2018). Accessed 21 Mar 2019

10. Ivchenko, I.Yu.: Modeliuvannia ekonomichnykh ryzykiv i ryzykovykh sytuatsii: navch. posib. (Simulation of economic risks and risky situations: teaching guide). Tsentr uchbovoi literatury, Kyiv (2007)

11. Dziaduk, T.V.: Pozytyvni ta nehatyvni efekty formuvannia merezhevykh pidpryemsv (Positive and negative effects of forming network enterprises). Investytsii: praktyka ta dosvid. 10, 36-38 (2010)

12. Martynenko, V.V.: Zahrozy ekonomichnii bezpetsi Ukrainy v konteksti vyklykiv hlobalizatsii (Threats to Ukraine's economic security in the context of the challenges of globalization). Ekonomichnyi chasopys-XXI. 7-8, 40-43 (2011)

13. Mayadunne, S., Park, S.: An economic model to evaluate information security investment of risktaking small and medium enterprises. International Journal of Production Economics. 182, 519-530 (2016).

14. Gozora, V.: Economic Security of small and medium enterprises. MEST Journal (Management Education Science and Society Technologies), 3(1), 114-119 (2015)

15. Status Report on European Telework. "Telework 1997”. Annual Report from the European Commission.

https://web.archive.org/web/20121120044825/http:// www.eto.org.uk/twork/tw97eto/ (1997). Accessed 21 Mar 2019

16. Blank, I.A.: Upravleniye finansovoy bezopasnostyu predpriyatiya (Management of enterprise financial security). Elha, Nika-Tsentr, Kyiv (2004) 